\title{
Comparison of Horticultural Therapy in Korea and Japan: History, Inspiration, and Education
}

\author{
Won Tae Zhang, Suk Young Yun*, and Byung Jin Choi \\ Department of Horticulture, Daegu Catholic University, Gyeongsan 38430, South Korea
}

\begin{abstract}
This study aimed to examine how the horticultural therapy that was originated in the US has influenced South Korea and Japan and developed in the two countries as an interim check to promote qualitative growth of horticultural therapy with the growing social attention. It also aimed to look into the background of how horticultural therapy was introduced in Japan (which introduced horticultural therapy around the same time as Korea), and the process of the introduction, and compare them with those of Korea in order to set the direction for horticultural therapy. Data was collected to prepare the chronological table of horticultural therapy in Korea and Japan and investigate the flow. Interviews were conducted with the professors who first opened a horticultural therapy course in university so as to determine the introduction background. The analysis results are summarized as follows: Horticultural therapy was created to give mental comfort and emotional purification to those concerned with horticulture that had concerns over social phenomena. In Korea, there had been a process of finding a way of getting mental comfort and emotional purification in the economic slowdown in the late 1990s. Since 2001, there have been more attention and demand for horticultural therapy. As a result, there has been a tendency of studying general horticultural welfare activities and professional horticultural therapy separately. In Japan, the environmental pollution that has arisen since 1970s led to a concern over social orientation in the relation between plants and humans. The academic conference of global researchers to establish the horticultural therapy studies influenced the introduction of horticultural therapy in Korea and Japan. Both countries had no operations and system, and developed them independently. They had similar directions to seek, such as the department of horticultural therapy, need for professional education, active introduction of hospital practice (internship), and security of operating budget. Horticultural therapy has many competencies and thus requires constant research and expansion.
\end{abstract}

Keywords: chronology, mental comfort, professional education

\section{Introduction}

Movements to use the energy of plants in therapy have been all over the world for a long time, and activities in gardens with plants have been prescribed as a therapy for patients with mental illnesses and neurosis (Relf, 1998b). There have been studies to examine the actual state of horticulture and gardening, learn the meaning and role of plants, and apply them to real life (Matsuo, 2005). Currently horticultural therapy is provided in educational institutions, hospitals, rehabilitation facilities and community centers in South Korea (Jea, 2015). The scope of subjects is also expanding from persons with 
disabilities to the general public (Cho et al., 2003). Horticultural therapy, which belongs to the broad range of humans and plans, involves the government, agricultural agencies, farmers, horticulturists, landscape architects, foresters, and various specialists in medical treatment, healthcare, and welfare (Nagano, 2003). Since horticultural therapy is a field that encompasses a variety of different areas, there are many different thoughts among specialists regarding the definition, scope or direction of horticultural therapy, as well as opinions about the job details, required knowledge and capabilities of horticultural therapists. This causes great confusion to people trying to learn horticultural therapy, discouraging them from studying it (Nagano, 2003).

Compared to the quantitative growth of horticultural therapy in Korea, there is not enough systematic research and social recognition for elevation of its status to state certification (Cho et al., 2007). Moreover, compared to other alternative treatments, horticultural therapy requires specific performance or expertise such as a unified evaluation method or clinical trials in order to increase utility and reliability (Han, 2007). Accordingly, with focus on the views of the American Horticultural Therapy Association (AHTA) that has been ahead in terms of establishing the foundation and system for horticultural therapy, it is necessary to examine the process of introducing the concept of horticultural therapy in Japan, which has introduced it around the same time as Korea in Asia. Moreover, there is a need to analyze the background in which horticultural therapy first began in Korea and Japan based on the research materials thus far, and how the curriculums of horticultural therapy have been implemented by interviewing related figures. In Korea, sources of Korean Society for Horticultural Science describe that horticulture-related specialists began seminars and researches related to horticultural therapy in the 1980s (Pak et al., 2013). However, there is no philosophical consideration about how horticulture specialists developed horticultural therapy today in terms of social background or change in perception. Determining the foundation and trend of horticultural therapy will make it possible to wisely cope with various ripple effects of changes in form of horticultural therapy in the future.

By conducting this study and applying the findings from events in the past to the countless issues and phenomena in Korea, it will be possible to supply horticultural therapy or well-being through horticulture that is unique to Korea. Furthermore, continuous research on this will lead horticultural therapy to settle itself as a systematic field of study certified by the state and lead to a more developed future (Cho, 2013).

Thus, this study carried out an interim examination of the increased attention and research trend about horticultural therapy, collected and organized data on the introduction process of horticultural therapy in Korea and Japan to secure internal stability of qualitative along with quantitative growth of horticultural therapy, and examined the researchers and related specialists that were the first to start related lectures in universities in the process of introducing horticultural therapy. This study intends to set the research direction for horticultural therapy and propose horticultural therapy unique to Korea by analyzing the interviews with related specialists by country in terms of development of curriculums, operation and system, and direction and vision of professionalism of horticultural therapy.

\section{Research Methods}

\section{Data collection}

Data was collected and organized to analyze the process in which horticultural therapy was introduced. Official submitted documents and data were collected from Research Information Sharing Service (RISS) (http://www.riss.kr), Korean Horticultural Therapy \& Wellbeing Association (KHTA) (http://www.khta.or.kr), Korean Society of People, Plants and Environment (http://www.ppe.or.kr), National Institute of Informatics in Japan (http://ci.nii.ac.jp), Japan Horticulture Therapy Society (http://www.jht-assc.jp), and Japanese Society of People-Plant Relationships (http://www.jsppr.jp). 


\section{Interviews}

Using the collected data, we determined the ones who first established major courses related to horticultural therapy in universities in the process of introducing horticultural therapy in Korea and Japan, as well as related specialists. The interviews were conducted by asking questions about the background for introducing horticultural therapy, operations and systems, and direction and vision of professionalism. The details are as follows. For Korea, we met and interviewed emeritus professor Chae-Kyu Sang who applied for 'Horticultural Therapy' as an undergraduate course at Hyosung Women's University (currently Daegu Catholic University) in 1986, and Konkuk University professor Ki-Cheol Son who compiled the biggest number of books in the keyword 'horticultural therapy.' For Japan, we met and interviewed Kyushu University emeritus professor Matsuo Eisuke who opened the undergraduate course 'Socio-horticulture' in the Faculty of Agriculture at Kagoshima University in 1991 (Table 1).

\section{Results and Discussion}

\section{The process of introducing horticultural therapy in South Korea}

In South Korea, horticultural therapy of the United States (US) was introduced by professor Byoung-Hwa Kwack (former Korea University Department of Horticulture Science) in 1984 (Matsuo, 1998). There was a special lecture on 'Newly Developing Field of Horticulture and Horticultural Science' at the 22nd Conference of the Korean Society for Horticultural Science held in Kangwon National University (Pak et al., 2013). This was about the process of horticultural therapy that makes people engage with nature through horticulture and give emotional stability to their minds.

Later, the base was gradually expanded as horticultural therapy was used for vocational training at institutes for persons with disabilities and special schools after the 1988 Summer Paralympics. Then, professor Chae-Kyu Sang at Hyosung Women's University (currently Daegu Catholic University), who had been the dean at the time, applied for the undergraduate course 'Horticultural Therapy' in the Department of Horticulture in 1986, and the course was finally opened in 1991. After that, lectures on horticultural therapy were given at Chonnam National University Department of Horticulture, Hankyong National University Department of Horticulture, and Konkuk University Graduate School.

Upon entering the 1990s, horticultural therapy began to be used in hospitals for treatment and rehabilitation. In 1994, Buk-Gu Heo, director of the Korean Horticultural Technology Research Institute, published the first book on horticultural

Table 1. The content of the interviews

\begin{tabular}{|c|c|c|}
\hline Interview format & Scope of question & Contents of questions \\
\hline \multirow{4}{*}{$\begin{array}{l}\text { Question } \\
\text { and } \\
\text { answer }\end{array}$} & $\begin{array}{l}\text { Introduction of } \\
\text { horticultural therapy }\end{array}$ & $\begin{array}{l}\text { How did you first learn about horticultural therapy? } \\
\text { How difficult was it to open the first course of horticultural therapy in university? } \\
\text { How did you find out about the People-Plant Council symposium that started in } 1990 ? \\
\text { Who are the overseas researchers you met at the People-Plant Council? }\end{array}$ \\
\hline & $\begin{array}{l}\text { Operations and system of } \\
\text { horticultural therapy }\end{array}$ & $\begin{array}{l}\text { How should the national support policy of horticulture therapy be achieved? } \\
\text { Do you have any comments on the current horticulture therapy program system? }\end{array}$ \\
\hline & $\begin{array}{l}\text { Professionalism of } \\
\text { horticultural therapy }\end{array}$ & $\begin{array}{l}\text { Do you have any opinion of similar organizations related to horticulture therapy? } \\
\text { Do you have any suggestions to improve horticulture therapist professionalism? }\end{array}$ \\
\hline & $\begin{array}{l}\text { Vision of } \\
\text { horticultural therapy }\end{array}$ & $\begin{array}{l}\text { What do you hope the future of horticultural therapy will be? } \\
\text { What capacity should a horticulture-therapist develop in the future? }\end{array}$ \\
\hline
\end{tabular}


therapy titled 'Secret to Happiness and Horticultural Life' (Sim and Kwack, 1995). And the same year horticultural therapy was selected as the topic of the subcommittee meeting of the International Society for Horticultural Science in Kyoto, and thus Korea University professor Byoung-Hwa Kwack from Korea presented an academic research on 'Psychological Effects of Landscape Plants on Mental Health' (Sim and Kwack, 1995).

In 1995, an abstract on the topic of horticultural therapy (Chung, 1995) was registered for the first time in the Korean Society for Horticultural Science. In 1997, the first book in Korea (Son et al., 1997) to specifically include the term 'horticultural therapy' was published in the title 'Horticultural Therapy.' That same year, the Japanese book 'Horticultural Therapy: Treating the Body and Soul by Making Contact with Plants (Sim et al., 1997)' by Grosse Setsuko who studied horticultural therapy in the US in the 1990s was translated and published in Korea. Then 'Horticultural Therapy Research Group' was founded. In 1998, this was renamed to 'Korean Horticultural Therapy Research Group', and professor Ki-Cheol Son was elected the first chairman. That same year, the Korean Society of Plants, People and Environment (currently Society of People, Plants and Environment) was established with Korea University professor Woo-Kyung Sim at the center. Aside from Sim, many other specialists from different fields participated in the establishment, and researcher Sung-Hye Jeong presented a study on 'Development of Research on People, Plants and Environment and Current State of Various Countries.' That same year in July there was a presentation on the topic 'Towards a New Millennium of PeoplePlant Relationships' at the 5th People-Plant Symposium held in Australia (Relf, 1998a).

In 1999, a horticultural therapist training program was established in Konkuk Continuing Education Center, and also one in Korea University Institute for Education the following year in 2000. A horticultural therapist training program was then also established in Catholic University of Daegu Lifelong Learning Institute in 2002. At the same time, the department of horticultural therapy began to be established in graduate schools nationwide upon entering the 2000s. The department of horticultural therapy was established in Konkuk University in 2001, Soonchunhyang University in 2005, Korea University and Wonkwang University in 2006, and Graduate School of Health and Medical Science at Catholic University of Daegu in 2009. 'Korean Horticultural Therapy Association' was founded in 2001. This is an integration of 'Korean Horticultural Therapy Research Group' led by Konkuk University and 'Korean Society of Plants, People and Environment' led by Korea University with the agreement of mutual exchange. Professor Ki-Cheol Son was inaugurated as the first chairman. In 2003, 'Korean Horticultural Therapy Federation' was founded, which was renamed to Korean Horticultural Therapy \& Wellbeing Association (KHTA) after integrating with Korean Horticultural Therapy Association in 2008. 'Korean Society of Plants, People and Environment' was renamed to 'Korean Society of People, Plants and Environment' in 2008, and then to 'Society of People, Plants and Environment' in 2017. In 2010, 'Korean Horticultural Therapy \& Wellbeing Association (KHTA)' obtained permission of incorporated association and has come to take its form today (Table 2). Moreover, the Welfare Horticultural Therapist Registered qualification system is led by Korean Horticultural Therapy \& Wellbeing Association and operated by the training institutes of each region (university lifelong education centers selected in each region, Gyeongsangbuk-do Environment Training Institute, Jeju Horticultural Therapy \& Wellbeing Association). The curriculum is divided into Welfare Horticultural Therapist Supervisor, Welfare Horticultural Therapist Registered Grade I, II and III.

\section{The process of introducing horticultural therapy in Japan}

Horticultural therapy in Japan began in 1982 when Kyoto University Faculty of Agriculture Vegetable Flowers and Horticulture Laboratory reported the therapeutic practices of horticultural activities in various subjects in the US and Europe in the title of 'Treatment and Rehabilitation with Horticulture' (Kyoto University Faculty of Agriculture Vegetable 
Table 2. Timeline of key events relating to horticultural therapy in Korea

\begin{tabular}{|c|c|}
\hline Year & Content \\
\hline 1984 & $\begin{array}{l}\text { At the 22nd Korean Society for Horticultural Science, there was a reported of 'Newly developing field of horticulture and } \\
\text { horticultural science' by Beyoung-Hwa Kwack of Korea university. }\end{array}$ \\
\hline 1986 & $\begin{array}{l}\text { Chae-Kyu Sang from Hyosung Women's university(Daegu Catholic university) first taught 'Introduction of horticultural therapy' } \\
\text { course for undergradute students. }\end{array}$ \\
\hline 1991 & $\begin{array}{l}\text { Hong-Yul Kim from Hyosung Women's university(Daegu Catholic university) first taught 'Horticultural Therapy' course for } \\
\text { undergraduate students. }\end{array}$ \\
\hline 1995 & $\begin{array}{l}\text { An abstract of horticultural therapy was published for the first time (S.H. Chung. Effects of Horticultural Therapy Program on } \\
\text { Therapy and Rehabilitation of Psychiatric Patients. J. Korean Soc. Hortic. Sci. 13(2):476-477). }\end{array}$ \\
\hline 1997 & The book about horticultural therapy was first published by Ki-Cheol Son (Horticultural Therapy, Seowon). \\
\hline 1997 & Horticultural Therapy Research Group was established. \\
\hline 1998 & Korean Society for Plants, People and Environment was established. \\
\hline 1999 & 'Horticultural therapy’ classes were offered at Konkuk continuing education center. \\
\hline 2001 & Korean Horticultural Therapy Association was established. \\
\hline 2001 & Graduate school of horticultural therapy was established at Konkuk university. \\
\hline 2003 & Korean Horticultural Therapy Federation was established. \\
\hline 2005 & Graduate school of horticultural therapy was founded at Soonchunhyamg university. \\
\hline 2006 & Graduate school of horticultural therapy was founded at Korea university and Wonkwang university. \\
\hline 2007 & Korean Horticultural Therapy Association was changed to Korean Horticultural Therapy \& Wellbeing Association. \\
\hline 2008 & Korean horticultural therapy \& wellbeing Association and Korean horticultural therapy federation were merged. \\
\hline 2008 & Korean Society for Plants, People and Environment was changed to Korean Society for People, Plants and Environment. \\
\hline 2009 & Graduate school of horticultural therapy was founded at Catholic university of Daegu. \\
\hline 2010 & Korean Horticultural Therapy \& Wellbeing Association was approved as a corporation. \\
\hline
\end{tabular}

Flowers and Horticulture Laboratory, 1982). Horticultural therapy of the US was introduced by Grosse Setsuko who studied horticultural therapy in the US in 1990s. In addition, it received even more attention from the Japanese citizens with the media's spotlight on the boom of horticultural activities and expansion of the value system in which people wanted mental consolation when the bubble economy burst in Japan (Toyota, 1998).

Around the same time, Sawada Midori who studied horticultural therapy in the US founded Japan Horticultural Therapy Society in 1995. This is incorporated as a nonprofit organization in 2006. Grosse Setsuko wrote a report on the current state of horticultural therapy in 1992 and mentioned horticultural therapy (Nagano, 2003). In 1996, a horticultural therapy club was operated at the Horticultural Therapy Garden in Towa, Iwate, and the 'Horticultural Therapy Garden Maintenance and Operation Plan' was drawn up at the social welfare center of Kawaguchi, and a horticultural therapy program was carried out the following year accordingly. In 1997, ‘nonprofit corporation Horticultural Therapy West Japan' was founded in Hyogo. This is incorporated as nonprofit organization in 2013 and is still in operation.

The meeting of the International Society for Horticultural Science was held in Kyoto in 1994. Horticultural therapy was selected as the topic of the subcommittee meeting, and horticultural therapists came from various parts of the world to give presentations. After that, there were reports of actual practices and demonstrations in various regions, and the awareness of horticultural therapy was promoted. Around that time, courses were established in junior colleges and universities nationwide, and the 'Theory of Horticultural Therapy' course was established in 2000 at the Environmental Horticulture in Minami Kyushu University, using the term 'horticultural therapy' for the first time in a course title. A regular course was established at Awaji Landscape Planning \& Horticulture Academy (currently University of Hyogo) in September 2002, 
and students qualified for graduation can now obtain the certification of 'Horticultural Therapist' in Hyogo after completing the one-year course. At first students could obtain the HTR certification by American Horticultural Therapy Association after a year of paid training (at least 2,000 hours) after graduation, but this system is currently abolished. Japanese Horticultural Therapy Association approves 'Horticultural Therapist Registered' (HTR). Since 2006, the bio-therapy department is established in Tokyo University of Agriculture, which qualifies students to take the examination for 'Horticultural Therapist Registered.' Moreover, civil lectures are held in various parts of Japan. The study course hosted by 'nonprofit corporation Japanese Horticultural Therapy Workshop' in Kanagawa, the horticultural therapy lecture hosted by 'nonprofit corporation Horticultural Therapy West Japan' in Hyogo, and the horticultural therapy course by IWAD Environmental Welfare and Rehabilitation College in Hiroshima are schools approved by Japanese Horticultural Therapy Association to obtain qualification for examination of 'Horticultural Therapist Registered'.

Since 2002, Japan Association of University and College for Business Education (JAUCB) established a system to obtain the certification of a horticultural therapist arbitrarily upon completing a certain curriculum. The purpose was for the Japanese Society of People, Plants and Environment to integrate various certifications since there were many kindred organizations or associations arbitrarily issuing certifications. The certification system was enacted in April 2005. More specifically, it was divided into three types, such as Horticultural Therapist Assistant (HTA), Horticultural Therapist Registered (HTR), and Master Horticultural Therapist (HTM). In 2008, this became independent from Japanese Society of People, Plants and Environment and was transferred to Japanese Horticultural Therapy Association (Oura, 2013).

As part of practical training, three universities such as Osaka Kawasaki Rehabilitation University, Fukushima College and Kobe Women's University, and six colleges such as Sapporo International University, Osaka Shin-ai College and Kyushu University of Health and Welfare established the course to obtain 'Horticultural Therapist' certificate approved by JAUCB. In these courses, students are to learn about medical science, social welfare and psychology in addition to horticulture and horticultural therapy. Since 2007, students can now obtain the Horticultural Therapist certificate of JAUCB at Kyushu University of Health and Welfare and Osaka Kawasaki Rehabilitation University for the first time in Japan (Table 3).

Table 3. Timeline of key events relating to horticultural therapy in Japan

\begin{tabular}{|c|c|}
\hline Year & Content \\
\hline 1982 & Practical cases of horticultural therapy and rehabilitation in the United States and Europe were reported at Kyoto university. \\
\hline 1991 & Eisuke Matsuo from Kagoshima university taught 'Socio-horticulture' undergraduate classes. \\
\hline 1992 & $\begin{array}{l}\text { A status report of horticultural therapy was published for the first time by Setsuko Grosse (Horticultural Therapy, Japan greening } \\
\text { center). }\end{array}$ \\
\hline 1994 & $\begin{array}{l}\text { The International Horticultural Congress was held on the topic of 'The beautification of human life and its environment through } \\
\text { horticultural science' in Kyoto. }\end{array}$ \\
\hline 1995 & Japan Horticultural Therapy Society was established. \\
\hline 1997 & Horticultural Therapy West Japan was established. \\
\hline 2000 & Minami Kyushu University opened ‘Theory of Horticultural Therapy’ undergraduate course. \\
\hline 2001 & Japanese Society of People-Plant Relationships was established. \\
\hline 2002 & Japan Association University and College for Business Education(JAUCB) constructed certified horticultural therapist system. \\
\hline 2005 & $\begin{array}{l}\text { A horticultural therapist system certified by Japan Association University and College for Business Education(JAUCB) was } \\
\text { established. }\end{array}$ \\
\hline 2007 & $\begin{array}{l}\text { Kyushu University of Health and Welfare and Osaka Kawasaki Rehabilitation University were qualified as Horticultural } \\
\text { Therapists program that certified by JAUCB. }\end{array}$ \\
\hline 2008 & Japanese Horticultural Therapy Association was established. \\
\hline
\end{tabular}




\section{Interview with specialists}

\section{Process of introducing horticultural therapy}

Using the data collected from the documents, we determined the professors who first established courses in horticultural therapy at universities around the time it was introduced in Korea and Japan. We also found out the authors who compiled the biggest number of books with horticultural therapy as the keyword on RISS in Korea. Interviews were conducted with these subjects in Korea and Japan. In Korea, we interviewed Hyosung Women's University (currently Catholic University of Daegu) emeritus professor Chae-Kyu Sang who opened 'Horticultural Therapy' as a curriculum when the Department of Horticulture was established in 1986, and Konkuk University professor Ki-Cheol Son who turned out to be the author of most books, 12 out of 498, on RISS as well as the adviser of the biggest number of theses, 27 out of 453 on horticultural therapy. The details are as follows.

To determine the process and background of introducing horticultural therapy, we asked the respondents about the time and route in which they learned about horticultural therapy. The result showed that there was no exchange at all between Korean and Japanese researchers from the late 1980s to early 1990s, and then some exchange intermittently in the late 1990s as some scholars translated books related to horticultural therapy. In Japan, Diane Relf served as visiting professor at Kagoshima University in 1993 with the influence of Matsuo Eisuke and had quite an impact on Japan. Horticultural therapy tended to be widespread in both Korea and Japan due to American associations and researchers, such as the fact that they first encountered horticultural therapy after reading the paper by Diane Relf of Virginia Tech in the US in the late 1960s. In Japan there was agriculture focused on mass production in the 1960s, and promoted civic awareness in demanding food that is safe from environmental pollution, green zone loss and pesticide pollution in the 1970s. In Korea, there was agriculture focused on production in the 1980s, and expanded value system to gain consolation of the mind in the late 1990s. Such social phenomena according to the phases of the times in both countries had influence over the expansion of the base for horticultural therapy (Table 4).

Table 4. The interview related to the introduction of horticultural therapy

\begin{tabular}{|c|c|c|c|c|}
\hline \multirow{2}{*}{ Response contents } & Country & Content class & ication & \multirow{2}{*}{ Conclusion } \\
\hline & Korea $\mathrm{Ja}$ & Consciousness & Incident & \\
\hline
\end{tabular}

There were no exchanges between Korean and Japanese
researchers until the early 1990s.
In 1993, Dr. Relf had lectures as visiting professor at
Kagoshima University.
In the late 1960s, after reading the paper of Dr. Relf in
Virginia Tech, researchers studied horticultural therapy for the
first time.
In 1986, continuous exchanges happened since the first
meeting with Dr.Relf at the International Horticultural
Congress (University of California, Davis Campus).
In the 1960s, mass production of agriculture began.
In the 1970s, promoting civic awareness required safety from
environmental pollution, green zone loss, and insecticide
pollution.
In the 1980s, production-oriented agriculture began.
In the late 1990s, expansion of values to get comfort in mind.




\section{Operations and systems of horticultural therapy}

Japan's top priority is to how horticultural therapy is used by humans and plants, and thus Japan established Japanese Horticultural Therapy Association after founding Society of People-Plant Relationships. On the other hand, in Korea, the increasing attention and demand for horticultural therapy led to mixed use of the scope and purpose of general horticultural welfare and professional horticultural therapy. Thus, to give a professional identity to horticultural therapy, Korean Horticultural Therapy \& Wellbeing Association (KHTA) and Society of People, Plants and Environment have come to mutually cooperate and share their roles. It seems that each country does not have anything finalized in terms of operations or systems, but has its own way. Moreover, Japan has been smoothly opening up courses based on constant research accomplishments made since the 1970s such as at the International Society for Horticultural Science. However, Korea faced difficulty in opening courses due to lack of information and knowledge sharing as well as communication in the Ministry of Education in the 1980s (Table 5).

\section{Direction for professionalism of horticultural therapy}

For horticultural therapy today, it is important to focus on the thought about the natural relationship between nature and humans in terms of environment and education, even though it involves crafts using plants and recycling, based on which there is an emphasis on the fact that horticultural therapy has various competencies along with nature. In particular, there were opinions in Korea about the fact that various therapeutic approaches outdoors in addition to indoors are also effective. Both countries claimed that there is a need for other alternative therapies such as animal-mediated or forest therapy in nature, as well as collaboration with other healthcare professionals. They said it is also necessary to establish a system to have hospital training (internship) systematically at an educational institute. Moreover, they positively reviewed joint

Table 5. The interview related to operations and system of horticultural therapy

\begin{tabular}{|c|c|c|c|c|c|}
\hline \multirow{2}{*}{ Response contents } & \multicolumn{2}{|c|}{ Country } & \multicolumn{2}{|c|}{ Content classification } & \multirow{2}{*}{ Conclusion } \\
\hline & Korea & Japan & Consciousness & Incident & \\
\hline $\begin{array}{l}\text { The } 1980 \text { s was a time of revival of science and society as a } \\
\text { whole. }\end{array}$ & & $\bullet$ & & $\bullet$ & $\begin{array}{l}\text { In each country, there was nothing } \\
\text { set in operation and system, and it } \\
\text { developed independently. }\end{array}$ \\
\hline $\begin{array}{l}\text { The first step was to understand how horticultural therapy } \\
\text { was being used by humans and plants. }\end{array}$ & & $\bullet$ & $\bullet$ & & $\begin{array}{l}\text { Horticultural therapy related } \\
\text { associations and societies had }\end{array}$ \\
\hline $\begin{array}{l}\text { Establishment of Japan Horticultural Therapy Association } \\
\text { after Japanese Society of People-Plant Relationships. }\end{array}$ & & $\bullet$ & & $\bullet$ & their own introduction. \\
\hline $\begin{array}{l}\text { It was necessary to differentiate between welfare horticulture } \\
\text { activities and professional horticultural therapy. }\end{array}$ & - & & $\bullet$ & & \\
\hline $\begin{array}{l}\text { Korean Horticultural Therapy \& Wellbeing Association and } \\
\text { Korean Society for People, Plants and Environment share } \\
\text { mutual cooperation and work. }\end{array}$ & $\bullet$ & & & $\bullet$ & \\
\hline $\begin{array}{l}\text { It was unfamiliar to horticultural researchers and related } \\
\text { people. }\end{array}$ & - & & $\bullet$ & & $\begin{array}{l}\text { People felt difficulty in } \\
\text { understanding new kind of science }\end{array}$ \\
\hline $\begin{array}{l}\text { The International Horticultural Society and other research } \\
\text { achievements have made it possible to open smooth lectures. }\end{array}$ & & - & & $\bullet$ & $\begin{array}{l}\text { horticultural therapy at the time of } \\
\text { introduction. }\end{array}$ \\
\hline $\begin{array}{l}\text { Due to lack of information, knowledge exchange and } \\
\text { communication with Ministry of Education, there was some } \\
\text { difficulty in opening lecture. }\end{array}$ & $\bullet$ & & & $\bullet$ & \\
\hline
\end{tabular}


research by specialists in various fields. Korea suggested the possibility of development in independent horticultural therapy by seeking various approaches affording to the knowledge background of each specialist. This turned out to be the common element in the direction that aims for professional horticultural therapy that sets goals and systematically carries out horticultural programs fit for therapeutic purpose, distinguished from the actual situation in which there are so many kindred organizations related to horticultural therapy as well as one-time horticultural experiences in both countries. Furthermore, Japan suggested the possibility of more specialized and focused development by subdividing and fragmenting horticultural therapy (Table 6).

\section{Vision of horticultural therapy}

According to Table 7, horticultural therapy needs to be constantly expanded and studied. Both countries need research that does not focus only on technology development and learning. In the use of the term, there is no misunderstanding among ordinary citizens in Japan that the term 'horticultural therapy' refers to treating the plants. On the other hand, in Korea there is occasionally a misunderstanding about the term that it is treating the plants. Both Korea and Japan claimed that horticultural therapists must enhance their knowledge, humane competencies and social responsibility, and that there must be constant efforts to secure budgets and publicize horticultural therapy despite difficult times of reduced budget due to the national policy and social phenomenon. Furthermore, they claimed that it is necessary to unify various groups in order to promote quality and social confidence of horticultural therapy, and secure national approval, which requires continuous harmony. In particular, many of those hosting such groups have unique personalities and thus may have different views, but ironically there might be positive effects in making most use of these characters. As a result of examining the similarities between Korea and Japan, it is necessary to strengthen operations such as budgeting as well as education on

Table 6. The interview related to professionalism of horticultural therapy

\begin{tabular}{|c|c|c|c|c|c|}
\hline \multirow{2}{*}{ Response contents } & \multicolumn{2}{|c|}{ Country } & \multicolumn{2}{|c|}{ Content classification } & \multirow{2}{*}{ Conclusion } \\
\hline & Korea & Japan & Consciousness & Outlook & \\
\hline $\begin{array}{l}\text { Even though crafts that utilize recycling together with plants, } \\
\text { it is important to think about the natural relationship between } \\
\text { nature and human in terms of environment and education. }\end{array}$ & $\bullet$ & $\bullet$ & $\bullet$ & & $\begin{array}{l}\text { Horticultural therapy has many } \\
\text { abilities. }\end{array}$ \\
\hline $\begin{array}{l}\text { It is effective to have various therapeutic approaches in indoor } \\
\text { as well as outdoors. }\end{array}$ & $\bullet$ & & • & & \\
\hline $\begin{array}{l}\text { It is necessary to establish a system in which hospital training } \\
\text { (internship) can be carried out institutionally. }\end{array}$ & $\bullet$ & $\bullet$ & $\bullet$ & & $\begin{array}{l}\text { Collaboration with other } \\
\text { alternative therapies is important. }\end{array}$ \\
\hline Collaboration with healthcare professionals is required. & & $\bullet$ & $\bullet$ & & \\
\hline $\begin{array}{l}\text { Collaboration with other alternative therapies such as } \\
\text { animal-mediated or forest therapy is needed. }\end{array}$ & $\bullet$ & & $\bullet$ & & \\
\hline $\begin{array}{l}\text { Enhancement of development potential through joint research } \\
\text { by experts in each field. }\end{array}$ & $\bullet$ & & & & $\begin{array}{l}\text { There are many experts involved } \\
\text { in horticultural therapy. }\end{array}$ \\
\hline $\begin{array}{l}\text { Explore various approaches based on expert knowledge } \\
\text { background. }\end{array}$ & • & & $\bullet$ & & \\
\hline $\begin{array}{l}\text { Possibility of future development by independent horticultural } \\
\text { therapy according to expert's knowledge background. }\end{array}$ & $\bullet$ & & & $\bullet$ & \\
\hline $\begin{array}{l}\text { Subsegmentation of horticultural therapy and possibility of } \\
\text { development by subdivision. }\end{array}$ & & $\bullet$ & & $\bullet$ & \\
\hline
\end{tabular}


business management rather than techniques or education about horticultural therapy itself. Moreover, it is necessary to first create an environment where several groups related to horticultural therapy come together in harmony through communication and join forces. This will be the solution to the tasks of horticultural therapy such as continuous expansion, unification of terms and integration of related groups. The results of interviews with Korean and Japanese specialists above are summarized in terms of incidents, consciousness and prospects (Table 7).

\section{Conclusion}

This study collected and summarized data and listed them in chronological order to determine how horticultural therapy was introduced in Korea and Japan. Moreover, it determined the researchers and related specialists that opened courses in universities for the first time in Korea and Japan, the process in which horticultural therapy was introduced in each country, as well as operations and systems of horticultural therapy, and direction and vision of professional horticultural therapy. Accordingly, it was found that specialists in various fields are participating in horticultural therapy, and thus it is necessary to seek the possibility of development using this fact.

For that reason, first, unlike Japan Horticulture Therapy Society and Japanese Society of People, Plants and Environment, Korean Horticultural Therapy \& Wellbeing Association (KHTA) and Korean Society of People, Plants and Environment are in close mutual cooperation, which can be a driving force and strength for development of horticultural therapy unique to Korea. Second, there is a need for active participation of horticultural therapists so that horticultural therapy can be carried out in a team with medical care, health and welfare to enhance its utility. To this end, it is necessary to promote them to the level of state certification by communicating and integrating with various organizations related to horticulture. Third, since horticultural therapists are the most important ones in the field that requires horticultural activities or therapy, it is important for educational institutes or organizations training horticultural therapists to provide and develop territories for their education and activities in response to the quantitative growth. This requires the attitude that does not focus only on technology development and learning. This must also be accompanied by plans and considerations about securing government budget in expansion of the base as well as activities. Finally, it is necessary to promote the quality of horticultural therapy by distinguishing horticultural activities from professional horticultural therapy, establish subdivided learning programs, and developing programs for each symptom of the subjects. Furthermore, there is a need to utilize communication

Table 7. The interview related to vision of horticultural therapy

Response contents
$\begin{aligned} & \text { Horticultural therapy research that does not focus on } \\
& \text { technology development and learning is needed. }\end{aligned}$
$\begin{aligned} & \text { There is no misunderstanding by ordinary citizens that the } \\
& \text { term 'Horticulture therapy' treats the plant itself. }\end{aligned}$
$\begin{aligned} & \text { Horticultural therapists should also be concerned about } \\
& \text { budgeting. }\end{aligned}$
$\begin{aligned} & \text { The government budget is being cut down politically. } \\
& \text { It is necessary to unify several groups to improve the quality } \\
& \text { of horticultural therapy and social confidence. }\end{aligned}$
\begin{tabular}{l} 
It should actively take advantage of the unique person. \\
\hline
\end{tabular}


technology using social networking services or applications through which various horticultural therapists and subjects all over the country can easily meet and communicate. Developing, studying and seeking possibilities for horticultural therapy to promote qualitative growth will enable Korea to supply and continuously develop horticultural therapy unique to the nation.

\section{References}

Cho, J.H. 2013. Analysis of horticultural therapist education system in America and Korea. Master's thesis, Korea University, Seoul, South Korea.

Cho, M.K., S.I. Jung, K.C. Son, and M.K. Kim. 2003. Effect of gradual application of horticultural therapy programs on the changes of assertiveness and interpersonal relationship of the chronic schizophrenia. Korean J. Hortic. Sci. Technol. 21(Suppl 1):115.

Cho, W.K., M.K. Cho, E.A. Lim, and K.C. Son. 2007. Studies of the actual conditions of horticultural therapists' activities and the promotion of their status. J. Korean Soc. People Plants Environ. 10(2):120-138.

Chung, S.H. 1995. Effects of horticultural therapy program on therapy and rehabilitation of psychiatric patients. Proc. Korean Soc. Hortic. Sci. 13(2):476-477.

Han, D.H. 2007. A study on the current state and the developmental direction of horticultural therapist training course. Doctoral dissertation, Jeju University, Jeju, South Korea.

Jea, E.S. 2015. Development and application of the educational horticulture program for the creative experience curriculum in elementary school. Doctoral dissertation, University of Seoul, Seoul, South Korea.

Kyoto University Faculty of Agriculture Vegetable Flowers and Horticulture Laboratory. 1982. Treatment and rehabilitation through gardening. New Semester in Kyoto University 113:28-29.

Matsuo, E. 1998. Exploring horticulture therapy. Green Information. 147:41-42

Matsuo, E. 2005. Recommendation of social horticulture. Tokyo, Japan: Noubunkyo Pub.

Nagano, A. 2003. Current situation of horticultural therapists education and its task to cope. Bulletin of Koshien junior college 22:45-50

Oura, S. 2013. The actual condition of Japan and overseas horticultural therapy. Nogyo Oyobi Engei (Agric. Hortic.) 88(1):51-55.

Pak, C.H., J.K. Suh, K.C. Son, and M.R. Huh. 2013. Horticultural therapy. History of Horticulture in Korea: Celebrating 50 years of Korean Society for Horticultural Science (pp.357-359). Wanju, Korea: Korean Society for Horticultural Science.

Relf, D. 1998a. Moving Toward a New Millennium in People-Plant Relations. In: M.D. Burchett, J. Tarrao and R. Wood (Eds.), Towards a New Millennium in Peop!e-Plant Relationships (pp.1-7). Sydney, Australia: University of Technology, Sydney Printing Services.

Relf, D. 1998b. The role of horticulture in human well-being and quality of life. J. Korean Soc. People Plants Environ. 1(1):12-21.

Sim, W.K. and B.H. Kwack. 1995. Psychological effects of ornamental plants on mental health in Korea. J. Korean Inst. Landsc. Archit. 23(1):1219-1222.

Sim, W.K., E.I. Kim, T.G. Song. 1997. Horticultural therapy: Treatment of mind and body by contact with plants. Seoul, South Korea: Seoil Pub.

Son, K.C., S.K. Park, H.O. Boo, K.Y. Paek, S.H. Lee, and B.G. Heo. 1997. Horticultural therapy. Seoul, South Korea: Seowon Pub.

Toyota, M. 1998. The pleasures of gardening and horticultural therapy: Let's start with horticultural therapy. Tokyo, Japan: Ienohikarikyoukai Pub. 